\title{
EVOLUÇÃO ESTRUTURAL DO DOMÍNIO EXTERNO DA FAIXA BRASÍLIA NO SUDOESTE DE MINAS GERAIS: REGISTROS DE UMATECTÔNICA PRÉ-BRASILIANA
}

\author{
CLÁUDIO DE MORISSON VALERIANO*, JULIO CESAR HORTA DE ALMEIDA*, LUIZ SERGIO AMARANTE \\ SIMÕES**, BEATRIZ PASCHOAL DUARTE*, HENRIQUE LLACER ROIG* \\ \& MONICA HEILBRON*
}

\begin{abstract}
STRUCTURAL EVOLUTION OF THE BRASÍLIA BELT EXTERNAL DOMAIN IN THE SOUTHWESTERN MINAS GERAIS: RECORDS OF PRE-BRASBLIANO AGE TECTONICS The Brasilia Belt is a Neoproterozoic (790-600 Ma.) fold-thrust belt developed at the western margin of the São Francisco craton (SFC). In the southern segment of the belt, the main allochthonous tectonic elements are, from top to bottom, the Passos Nappe (PN) and the Externai Allochthonous Domain (EAD). Both override the cratonic cover (Bambuí Group) at the southwestern border of the SFC. Within the EAD, the scope of this paper, structural and lithological relationships led to the individualization of six thrust sheets of low metamorphic grade rocks: I-metasediments of psamo-pelitic association, with subordinated conglomerates; II- an Archean granite-greenstone association (the Piumhi greenstone-belt); III- a turbiditic succession of médium to distai facies, whose source área involved rocks of the previous thrust sheet; IV- chromitite-bearing ultramafic schists; V- quartzitic metaconglomerates, metarenites and metapelites, with subordinated banded iron formation and manganesiferous graphitic slates; VI- same lithology as thrust sheet I.

Kinematic indicators, especially stretching lineations, indicate that the internai deformation fabric of the EAD records an important pre-Brasiliano northward verging tectonic event that hás been preserved during thrust stacking of the Brasilia belt towards the SFC, on top of the Bambui group rocks.
\end{abstract}

Keywords: Brasilia belt; Brasiliano orogeny; Neoproterozoic; thrust sheets; Bambuí group

RESUMO A Faixa Brasília é um cinturão de dobras e cisalhamento Neoproterozóico (790-600 Ma.) desenvolvido à margem ocidental do Craton do São Francisco (CSF). No segmento meridional da faixa, os principais elementos tectônicos alóctones são, do topo para a base, a Nappe de Passos (NP) e o Domínio Alóctone Externo (DAE). Ambos cavalgam as rochas do Grupo Bambuí, que constitui a cobertura cratônica à margem sudoeste do CSF. No âmbito do DAE, escopo deste trabalho, relações estruturais e litológicas permitiram a individualização de seis escamas tectônicas de rochas de baixo grau metamórfico: I-metassedimentos de natureza psamo (quartzítico)-pelítica, com conglomerados subordinados; II-uma associação gramto-greenstone arquearia (o greenstone-belt de Piumhi); III- uma sucessão turbidítica de facies média a distai, cuja área fonte envolveu as rochas da escama anterior; IV- xistos ultramáficos cromitíferos; V-metaconglomerados quartzíticos, metarenitos e metapelitos, subordinadamente com formação ferrífera bandada e filitos grafitosos manganesíferos; VI- mesma litologia da escama I.

$\mathrm{O}$ estudo de indicadores cinemáticos de transporte tectônico, especialmente lineações de estiramento, indicam que o fabric deformacional interno do DAE registra um importante evento de transporte tectônico para norte, de idade pré-brasiliana, que foi preservado durante o empilhamento por empurrões da Faixa Brasilia, em dirëção ao CSF, sobre as rochas do Grupo Bambuí.

Palavras-chaves: Faixa Brasília; Neoproterozóico; Brasiliano; Grupo Bambuí; tectônica de empurrões

INTRODUÇ̃̃O E OBJETIVOS A zona frontal da Faixa Brasília (Fuck et al 1993,Fuck 1994) tem uma estrutura dominada por cavalgamentos vergentes para o craton do São Francisco (Almeida 1977), tornando indispensáveis critérios de disposição estrutural, padrão deformacional e metamórfico, estratigrafia interna e de petrofácies como requisitos para correlações estratigráficas seguras.

Este trabalho resume resultados de oito anos de mapeamento geológico-estrutural sistemático na escala de 1:25.000, aliado aos estudos petrográficos, geoquímicos e geocronológicos da frente alóctone da Faixa Brasília meridional, na região entre as localidades de Carmo do Rio Claro e Piumhi. Como subsídio à compreensão da evolução tectônica deste importante compartimento tectônico, é apresentada uma nova proposta de distribuição cartográfica das unidades litotectônicas e de sua disposição estrutural, integrando a geologia da área de Piumhi no contexto do resto da frente alóctone da
Faixa Brasilia meridional. O estudo da distribuição espacial das lineações de estiramento, assumidas aqui como indicadoras da dirëção de transporte tectônico, evidencia a interferência de dois eventos de imbricação estrutural: um mais antigo, vergente para norte, e outro posterior, decorrente do encurtamento crustal da orogênese Brasiliana, vergente para ESE. Este último está associado à colocação da Nappe de Passos e ao recobrimento tectônico do Grupo Bambuí. Este quadro cinemático é interpretado à luz do contexto tectônico regional, e são discutidas as suas implicações sobre a evolução da Faixa Brasilia meridional e entidades geotectônicas adjacentes.

\section{COMPARTIMENTAÇÃO TECTÔNICA REGIONAL}

A porção meridional da Faixa Brasilia, na região da Represa de Furnas, foi previamente subdividida em três domínios tectônicos (Simões \& Valeriano 1990, Valeriano et al. 1989,

\footnotetext{
* Departamento de Geologia Regional e Geotectônica -Faculdade de Geologia-Universidade do Estado do Rio de Janeiro. Rua São Francisco Xavier n.

524/4006-A Maracanã. CEP 20559-900 Rio de Janeiro - RJ email: cmval@uerj.br

** Instituto de Geociências e Ciências Aplicadas-Universidade Estadual Paulista, Rio Claro, SP
} 
(a)
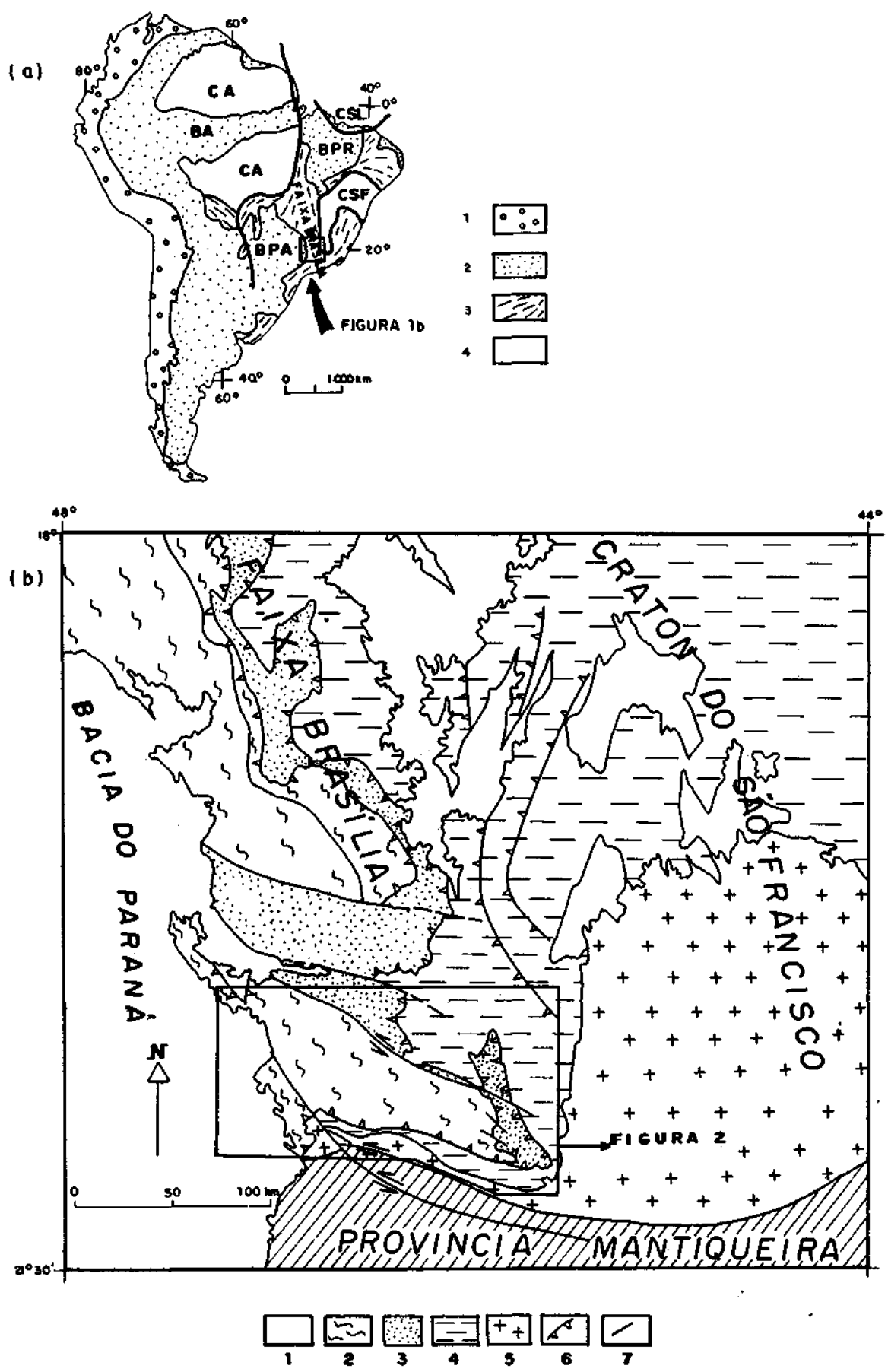

Figura l - Contexto geotectônico da porção meridional da Faixa Brasília. Modificado de Schobbenhaus et al. (1984), Barbosa etal. (1970) e Valeriano et al. (1993): a) Localização da área estudada em relação às principais unidades tectônicas do continente sul-americano: l- Cordilheira dos Andes; 2-Coberturas fanerozóicas indiferenciadas: BA-Bacia do Amazonas, BPA-Bacia do Paraná, BPR-Bacia do Parnaíba; 3- Faixas Móveis da Orogênese Brasiliana; 4- Principais crátons sin-brasilianos: CA-Cráton Amazônico, CSL-Cráton São Luís, CSF- Cráton do São Francisco (Brito Neves \& Cordani 1991). b) Mapa Tectônico simplicado da porção meridional da Faixa Brasília e unidades adjacentes (compilado de Simões \& Valeriano 1990, Barbosa et al 1970, Schobbenhaus et al. 1981, Szabó et al. 1993 ): l- Cobertura fanerozóica; 2- Domínio Alóctone Interno; 3- Domínio Alóctone Externo; 4- Cobertura Neoproterozóica (Grupo Bambuí); 5- Embasamento arqueanoapaleoproterozóico no Domínio Autóctone e no Cráton do São Francisco; 6-Empurrões, 7-Falhas subverticais.

Figure 1 :Geotectoniccontextofthe southern Brasília belt (modified from Schobbenhaus et al. 1984; Barbosa etal. 1970; and Valeriano et al. 1993): a) Location ofthe studied área in relation tothecontinental scaletectonic features: 1- Andean chain; 2-Undifferentiated Phanerozoiccover: BA- Amazonasbasin, BPA-Paraná basin, BPR- Parnaíba basin; 3- Brasiliano orogeny fold belts; 4-Major crátons: CA- Amazon, CSL- São Luiz, CSF-São Francisco (Brito Neves \& Cordani 1991). b) Simplified tectonic compartmentation of the southern Brasília belt and adjacent units (compiled from Simões \& Valeriano 1990, Barbosa et al. 1970, Schobbenhaus et al. 1981, Szabó et al. 1993 ): 1- Phanerozoic cover; 2- Internai Allochthonous Domain; 3- Externai Allochthonous Domain; 4-Neoproterozoic cover (Bambuí Group); 5- Archean to Paleoproterozoic basement within the Autochthonous and Cratonic Domains; 6-Thrust fault; 7- Subvertical fault. 


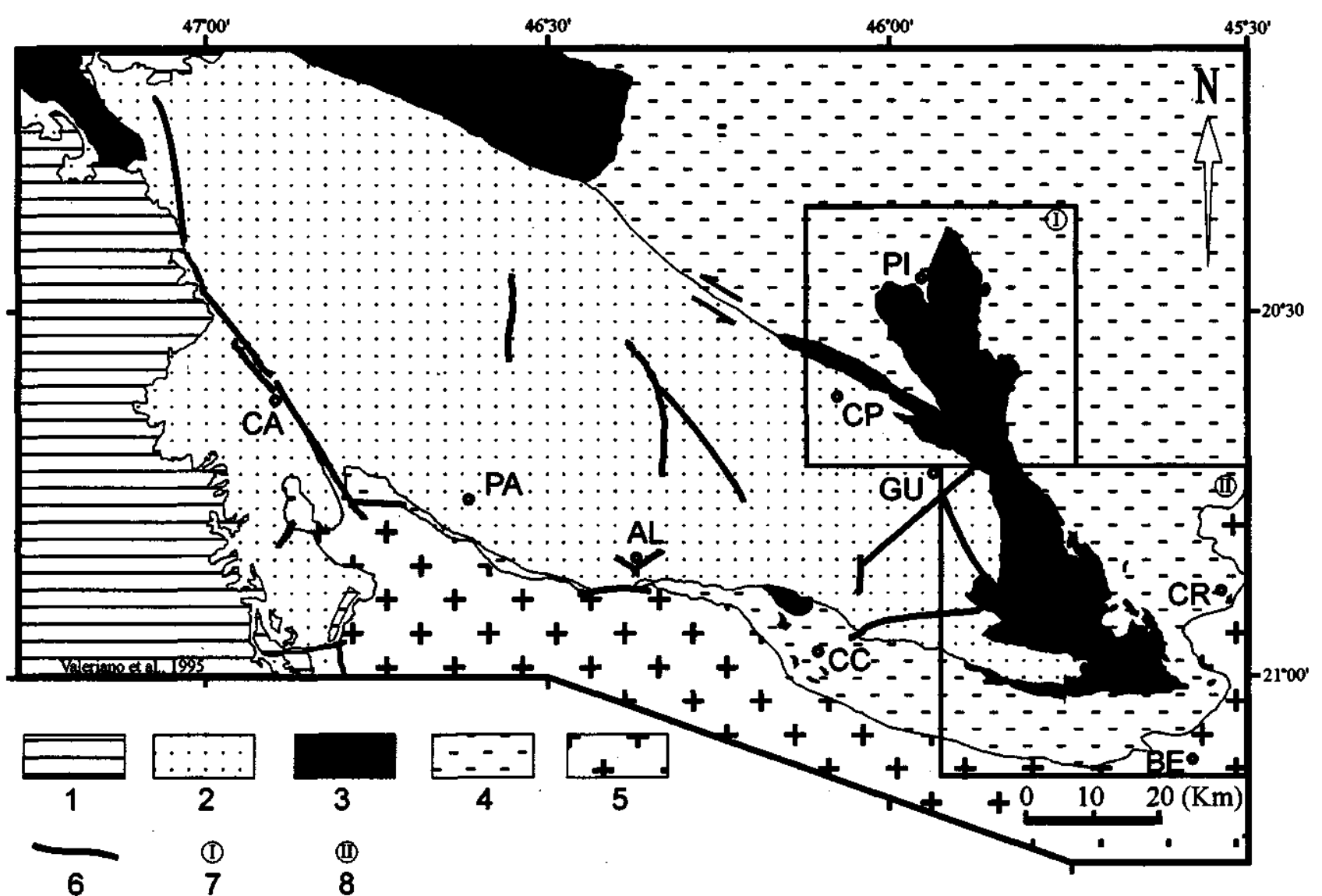

Figura 2 - Mapa tectônico simplicado da porção meridional da Faixa Brasília (modificado de Simões \& Valeriano 1990): 1-Cobertura fanerozóica; 2- Domínio Alóctone Interno (Nappe de Passos); 3- Domínio Alóctone Externo; 4- Cobertura Neoproterozóica (Grupo Bambui); 5- Embasamento arqueano a paleoproterozóico no Domínio Autóctone e no Cráton do São Francisco; 6- Falhas subverticais; 7- Localização da figura 3; 8- Localização da figura 4. Abreviatura das principais cidades: CA-Cássia, PA-Passos, AL-Alpinópolis, CC-Carmo do Rio Claro, BE-Boa Esperança, CR-Cristais, GU-Guapé,

CP-Capitólio, Pl-Piumhi.

Figure 2 - Simplified tectonic map of the southern Brasilia belt (modified from Simões \& Valeriano 1990). 1-Phanerozoic cover; 2- Internai Allochthonous Domain (Passos Nappe); 3- Externai Allochthonous Domain; 4-Neoproterozoic cover (Bambuí group); 5- Archean to Paleoproterozoic basement within the Autochthonous Domain and São Francisco craton; 6- Subvertical faults; 7- Location of figure 3; 8- Location of figure 4. Localities: CA- Cássia, PA- Passos, AL- Alpinópolis, CC-Carmo do Rio Claro, BE-Boa Esperança, CR-Cristais, GU- Guapé, CP-Capitólio, Pl-Piumhi.

Valeriano 1992), separados por superficies de cavalgamento de expressão cartográfica regional (Figs. 1 e 2), e compreendem os Domínios Alóctone Interno (DAI), Alóctone Externo (DAE) e Domínio Autóctone. Estes domínios tectônicos, aqui adotados, possuem características litológicas, de metamorfismo e de evolução deformacional contrastantes, abaixo resumidas.

Domínio Alóctone Interno (DAI) É o domínio tectônico estruturalmente superior, com graus de deformação e metamorfismo mais intensos, e cujo cavalgamento sobre todas as unidades subjacentes, incluindo o Grupo Bambuí autóctone, foi o último episódio de empilhamento tectônico (ca. 600 Ma.). Este domínio corresponde, na região, à Nappe de Passos reconhecida inicialmente por Schmidt \& Fleischer (1978) e por Teixeira \& Danni (1978), e posteriormente detalhada principalmente por Morales et al (1983), Oliveira et al. (1983), Correia (1986), Heilbron et al. (1987), Simões et al. (1988), Simões \& Valeriano (1990), Valeriano (1992) e Simões (1995). A nappe é constituída predominantemente por metassedimentos de baixo a alto grau metamórfico pertencentes ao Grupo Araxá e, possivelmente, ao Grupo Canastra.

Domínio Alóctone Externo (DAE) Estruturalmente sotoposto à Nappe de Passos, o DAE distribui-se ao redor desta unidade tectônica, cavalgando o Domínio Autóctone (Grupo Bambuí e seu embasamento). No segmento da Faixa Brasília em foco, este domínio corresponde ao que Valeriano (1992) denominou de Sistema de Cavalgamento Ilicínea-Piumhi, que se estende desde a região de Piumhi, contornando para sul a terminação frontal da Nappe de Passos pela Serra da Boa Esperança, e terminando nas proximidades de Carmo do Rio Claro sob a forma de vários klippen sobre o autóctone. A constituição litológica do DAE é extremamente diversificada, e inclui desde rochas arqueanas, pertencentes ao Greenstone-beltde Piumhi (Schrank 1982), até metassedimentos de baixo grau metamórfico de idades e posição estratigráfica ainda carentes de melhor informação, daí sujeitas a especulação. O enfoque deste artigo recai sobre o DAE, cuja com- 
partimentação litotectônica e evolução deformacional serão discutidas mais em detalhe abaixo.

Domínio Autóctone Inclui parte do Grupo Bambuí (Dardenne 1978, Magalhães et al. 1989), localmente representado pelo Sub-grupo Paraopeba, uma sucessão pelíticocarbonática e pelos metaconglomerados polimíticos do Membro Samburá (Branco 1956). Integra também o embasamento do Grupo Bambuí que, para leste, tem continuidade com a infraestrutura do Cráton do São Francisco (Teixeira \& Figueiredo 1991) e, para sul, com o Complexo Campos Gerais (Cavalcante et al. 1979). Em termos mais rigorosos, este domínio, ao menos nas imediações do conjunto alóctone, poderia ser classificado como parautóctone.

ESTRUTURAÇÃO E LITOLOGIA DO DOMÍNIO ALÓCTONE EXTERNO (DAE) Principais propostas prévias de compartímentação litotectônica $O$ Domínio Alóctone Externo tem sido alvo de atenção na literatura geológica desde a década de 40 devido às ocorrências de cromita a sul de Piumhi (Barbosa \& Lacourt 1940, Araújo 1943, Souza 1943), e às potencialidades minerais das rochas associadas. A Tabela 1 resume as principais propostas litoestratigráficas para a região e sua correspondência com a proposta apresentada neste artigo.

Tabela l-Quadro de correspondência entre as escamas discriminadas neste artigo e as unidades litoestratigráficas definidas em trabalhos anteriores.

Table 1 - Correspondence between the discriminated thrust sheets as proposed in this paper and the lithostratigraphic units as defined in previous papers.

\begin{tabular}{|c|c|c|c|c|}
\hline Este trabalho & Fritzsons Jr. et al. (1980) & Machado Filho et al. (1983) & $\begin{array}{l}\text { Schrank \& Abreu (1990) } \\
\text { Schrank \& Silva (1993) } \\
\end{array}$ & Valeriano (1992) \\
\hline Ecama VI & $\begin{array}{l}\text { Grupamento Intermediário: } \\
\text { quartzitos predominantes }\end{array}$ & $\begin{array}{l}\text { Grupo Canastra (Formação } \\
\text { Tromenta) }\end{array}$ & $\begin{array}{l}\text { porção quartzítica do Grupo } \\
\text { Paciência }\end{array}$ & $\begin{array}{l}\text { Sequência Serra da Boa Esperança } \\
\text { (Unidade Serra do Chapadão) }\end{array}$ \\
\hline Escama V & $\begin{array}{l}\text { Grupamento Intermediário: } \\
\text { sequência conglomerática superior, } \\
\text { sequência carbonosa-ferrffera }\end{array}$ & $\begin{array}{l}\text { Grupo Canastra (Formação } \\
\text { Tromenta) }\end{array}$ & $\begin{array}{l}\text { porçăo metassedimentar do } \\
\text { Grupo Lavapés }\end{array}$ & $\begin{array}{l}\text { Sequência Serra da Boa Esperança } \\
\text { (Unidade Serra da Mamona) + } \\
\text { lentes de Embasamento Alóctone }\end{array}$ \\
\hline Escama IV & $\begin{array}{l}\text { Grupamento Intermediário: } \\
\text { Sequência cromífera }\end{array}$ & Grupo Piumhi & $\begin{array}{l}\text { porção ultramáfica do } \\
\text { Grupo Lavapes }\end{array}$ & Embasamento Alóctone \\
\hline Escama III & $\begin{array}{l}\text { Grupamento Intermediário: xistos } \\
\text { grauváquicos, meta-grauvacas }\end{array}$ & $\begin{array}{l}\text { Grupo Canastra (Formação } \\
\text { Ilicínea) }\end{array}$ & $\begin{array}{l}\text { porção turbidítica do Grupo } \\
\text { Paciência }\end{array}$ & $\begin{array}{l}\text { Sequência Serra da Boa Esperança } \\
\text { (Unidade llicínea) }\end{array}$ \\
\hline Escama II & $\begin{array}{l}\text { Grupamento das rochas vulcânicas e } \\
\text { Intrusivas ácidas }\end{array}$ & $\begin{array}{l}\text { Grupo Piumhi } \\
\text { Complexo Campos Gerais }\end{array}$ & Grupo Ribeiråo Araras & Embasamento Aloctone \\
\hline Escama I & $\begin{array}{l}\text { Base do Grupamento Intermediário: } \\
\text { quartzitos, metabrechas e metapelitos }\end{array}$ & $\begin{array}{l}\text { Grupo Canastra (Formação } \\
\text { Tromenta) } \\
\text { Complexo Campos Gerais }\end{array}$ & $\begin{array}{l}\text { porção quartzítica do Grupo } \\
\text { Paciência }\end{array}$ & $\begin{array}{l}\text { Sequência Serra da Boa Esperança } \\
\text { (Unidade Serra do Chapadão) + } \\
\text { lentes de Embasamento Alóctone }\end{array}$ \\
\hline $\begin{array}{l}\text { Domínio } \\
\text { Autoctone }\end{array}$ & $\begin{array}{l}\text { Sequência Bambuí (Grupo } \\
\text { Paraopeba) }\end{array}$ & Grupo Bambuí & Grupo Bambuí & Grupo Bambuí Autóctone \\
\hline \multicolumn{5}{|c|}{ Área do trabalho em relação à Rampa Lateral de Capitólio (RLC) } \\
\hline $\begin{array}{l}\text { A norte e a } \\
\text { sul da RLC }\end{array}$ & A norte da RLC & A norte e a sul da RLC & A norte da RLC & A sul da RLC \\
\hline
\end{tabular}

O grande marco no avanço do conhecimento cartográfico deu-se durante a década de 70, com o mapeamento detalhado realizado por Fritzsons et al (1980). Este levantamento delimitou o greenstone-belt de Piumhi e trouxe à luz a primeira esquematização litotectônica local, no âmbito da área entre Piumhi e Santo Hilário. Estes autores identificaram e mapearam três associações litotectônicas que, da base para o topo, compreendem:

- Uma unidade basal, que poderia ser tipificada como uma associação granito-greenstone, inclui o Grupamento das Rochas Vulcânicas (ultramáficas a félsicas com frequente relíquias de texturas/estruturas primárias) e o conjunto de rochas Intrusivas Ácidas;

- Um Grupamento Intermediário, representado por metapsamitos e metapelitos variados em baixo grau metamórfico, e pelos corpos ultramáficos cromitíferos da região de Piumhi;

- A Sequência Bambuí, representado pelo Grupo Paraopeba, que inclui as facies pelítica, carbonática e conglomerática (facies Samburá).

Machado Filho et al. (1983), no mapeamento ao milionésimo do projeto RADAMBRASIL, demonstraram a continuidade das rochas da região de Piumhi para as áreas de Ilicínea e Carmo do Rio Claro, a sul da rampa lateral de Capitólio. Incluíram os metassedimentos de baixo grau metamórfico no Grupo Canastra, porém discriminaram cartograficamente os quartzitos da Formação Tromenta daqueles à base da Nappe de Passos, estendendo-os até a região de Ilicínea e Carmo do Rio Claro. Assinalam também a ocorrência de gnaisses a leste da cidade de Ilicínea. Assim como Fritzsons et al. (1980), também consideram o Grupo Bambuí estruturalmente superposto às rochas do DAE.

Schrank \& Abreu (1990) apresentam uma proposta de formalização das unidades litoestratigráficas do DAE, que denominam de Maciço de Piumhi, redefinindo as anteriormente apresentadas por Schrank (1982), que teve como base os levantamentos realizados por Fritzsons et al (1980). Este autores, corroborados por Schrank \& Silva (1993), definem três grupos, embora sem delimitação de seus contornos cartográficos: o Grupo Araras, que corresponde à associação granito-greenstone; o Grupo Paciência, constituído de uma sequência plataformal de metapsamitos quartzíticos e metapelitos com intercalações carbonáticas e uma sequência turbidítica; e o Grupo Lavapés, constituído por metassedimentos elásticos (quartzitos e metaconglomerados), xistos micáceos 
e grafitosos e formações ferríferas e grafitosas. Esta unidade também contém corpos máfico-ultramáficos cromitíferos.

\section{Proposta de organização litotectônica do DAE}

O DAE pode ser definido estruturalmente como um sistema de cavalgamentos (Boyer \& Elliot 1982), cuja organização estrutural é complexa, dominada por imbricação de escamas tectônicas (thrust sheets), empilhadas durante dois episódios de empurrão, como será discutido mais abaixo. Um mais antigo, vergente para norte, e que gerou a foliação principal e forte lineação de estiramento associados ao metamorfismo, e outro tardio, ligado à colocação da Nappe de Passos, ao final da orogênese brasiliana, vergente para ESE. Este último episódio de encurtamento crustal produziu megadobras flexurais em chevron, sem formação de foliação, com orientação axial predominante N-S, e empurrões de caráter rúptil. Do lado norte, a Nappe de Passos é limitada pelo importante sistema de Rampa Lateral de Capitólio, que atravessa o DAE e 0 desloca de modo levógiro (Fig. 2).

Com relação à segmentação da Faixa Brasília meridional, faz-se necessária uma distinção estrutural dos segmentos a norte e a sul da Rampa Lateral de Capitólio. O segmento a norte da rampa, que se estende de Santo Hilário até Piumhi (Fig. 3) é sensivelmente menos afetado pela compressão brasiliana relacionada à colocação da Nappe de Passos, em relação à porção a sul (Fig. 4). O segmento norte tem uma disposição sinclinorial sobre o Grupo Bambuí (Figs. 3 e 5a), preservando melhor 0 empilhamento por empurrões pré-brasilianos vergentes para o norte, e mostrando uma maior incidência de lineações de estiramento de direção aproximada nortesul. A porção a sul da rampa, diretamente recoberta pela Nappe de Passos, sofreu influência direta e mais severa da tectônica vergente para ESE, mostrando um maior número de falhas de empurrão deste evento e uma maior incidência de lineações de estiramento com orientação WNW-ESE.

A cartografia das superficies de empurrão internas ao DAE, a partir de truncamento de camadas, foliações e dobras, possibilitou a identificação de seis principais escamas tectônicas (thrust sheets) no setor norte do DAE (Fig. 3), isto é, o menos afetado pela Nappe de Passos. A individualização aqui proposta é baseada no mapeamento de superfícies de empurrão que truncam estruturas internas, na afinidade litológica e em critérios petrográficos. As escamas são abaixo relacionadas da base para o topo e ilustradas em mapa (Fig. 3) e seção esquemática (Fig. 5a). A Tabela 1 mostra a correspondência entre as escamas aqui definidas e as principais subdivisões litotectônicas adotadas por autores prévios.

ESCAMA I Repousa sobre o empurrão basal do DAE, sempre em contato com as rochas do Grupo Bambuí autóctone. Compreende uma larga predominância de metarenitos de grão médio a grosso, referidos como grânulo-quartzitos. Composicionalmente, são ortoquartzitos puros a micáceos e localmente feldspáticos. Sua feição textural típica é 0 arcabouço de conspícua seleção e arredondamento formado por quartzo monocristalino e, subordinadamente, microcristalino. Este metarenito contém frequentes intercalações de metapelitos, na forma de filhos quartzo-sericíticos esverdeados e localmente grada para termos conglomeráticos, monomíticos. Localmente, nas serras da Pimenta, do Fumai e da Paciência, este pacote contém intercalações descontínuas de metabrechas sedimentares de matriz quartzo-micácea com fragmentos angulosos a subarredondados de quartzito, filito, calcilutito, granito, gnaisse e de rocha metabásica. Foram medidos fragmentos de quartzito com diâmetro de até $1,5 \mathrm{~m}$ na serra do Fumai.

Pela abundância de quartzitos, as rochas desta escama sustentam as serras da Paciência, Fumai, Pimenta, do Chapadão, da Boa Esperança, e dos Vilelas. Os klippen de Cristais, da Serra da Tromenta e do Barreiro, dentre outros menores, sustentam cristas e pequenos tabuleiros em meio às baixadas do Grupo Bambuí.

ESCAMA II É constituída por um terreno granito-greenstone caracterizado por Machado \& Schrank (1989) como de idade arqueana, com base na datação U-Pb de $3.1 \mathrm{Ga}$ (intercepto superior da corda em três análises de zircão) em um gabro anortosítico intrusivo na sequência vulcânica. Nas imediações de Piumhi, predomina a associação metavulcanosedimentar, ao passo que para sul, até as imediações de Ilicínea, predominam largamente os ortognaisses com raras exposições de rochas do tipo greenstone. Apresenta deformação muito heterogénea, com núcleos pouco deformados, onde podem ser encontradas texturas e estruturas vulcânicas e plutônicas muito bem preservadas, descritas em detalhe por Schrank (1982), envoltos por zonas cisalhadas, com forte foliação. No setor a sul da rampa lateral de Capitólio, a leste de Ilicínea, Valeriano (1992) reporta uma datação K-Ar de $2251 \pm 26$ Ma., em hornblenda proveniente de um granito desta escama que, com base em análises geoquímicas de elementos maiores e traços, pertence a uma série de afinidade cálcioalcalina, contendo gabrodioritos, dioritos, tonalitos, granodioritos e granitos.

ESCAMA III Esta escama compreende um pacote metassedimentar de caráter turbidítico, correspondendo a parte da Unidade Ilicínea (Valeriano 1992) e também parte do Grupo Paciência, de Schrank \& Abreu (1990). Na figura 3 são discriminadas duas facies de turbiditos clássicos: uma de caráter relativamente mais proximal, caracterizada por ciclos granodecrescentes decimétricos, limitados na base por contatos erosivos, com gradação de arenitos grossos de cor negra até metapelito cinza; e outra mais distai, com ciclos centimétricos de metarenito fino e metassiltito gradando para metapelito (thin-bedded turbidites). Em porções mais preservadas, como a norte da rodovia MG-050, observam-se estruturas sedimentares reliquiares com organização típica de turbiditos, tais como estratificação planoparalela dos ciclos, laminação cruzada em metarenitos finos e metassiltitos, e laminação convoluta nos metapelitos, dentre outras. O estudo petrográfíco dos arenitos mostra uma proveniência da erosão do conjunto da escama II, com arcabouço formado por quartzo subangular monocristalino e policristalino de origem plutônica, cristaloclastos de plagioclásio e microclina, e abundantes litoclastos de granitóides e de rochas vulcânicas básicas, intermediárias e ácidas. Intraclastos pelíticos são frequentes. É importante ressaltar que não se observam clastos de quartzito, fato interpretado como uma indicação de que esta sequência é provavelmente mais nova do que a associação granitogreenstone (escama II) e mais antiga do que a sequência sedimentar da escama I.

Embora o conjunto granito-greenstone seja considerado embasamento da sequência turbidítica, não é clara a relação de contato, se por discordância sedimentar ou por empurrão. Por simplificação, os turbiditos são referidos como uma escama tectônica individual. 


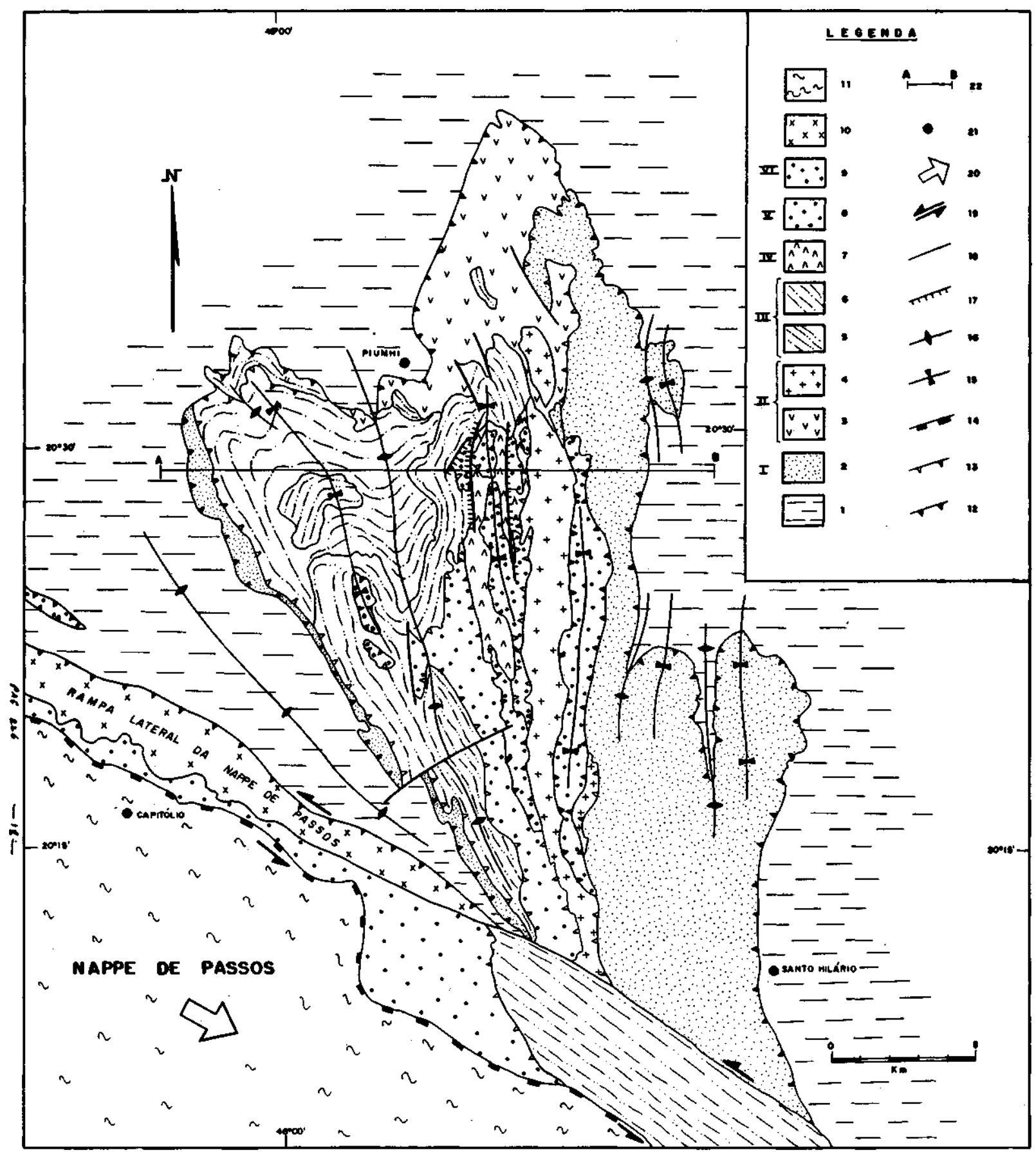

Figura 3 - Mapa litotectônico do setor norte do Domínio Alóctone Externo, onde algarismos romanos indicam o número da escama tectônica correspondente, 1- Grupo Bambuíautóctone; 2- Quartzitos efilitos (Escama I); 3- Associação greenstone-belt (Escama II); 4-Granitóides foliados (Escama H); 5- Sequência turbidítica, facies média (Escama III); 6- Sequência turbidítica, facies distai (escama III); 7- Xistos ultramáficos cromitíferos (Escama IV); 8-Predominância de metaconglomerados (Escama V); 9-Predominância de quartzitos muito recristalizados (Escama VI); 10- Ortognaisses (Escama l); II- Nappe de Passos; 12-Falha de empurrão principal; 13-Falha de empurrão subordinada; 14- Empurrão basal da Nappe de Passos; 15-Traço axial de sinformal; 16- Traço axial de antiformal; 17- Falha normal; 18- Falha subvertical indiscriminada; 19-Movimentação da rampa lateral da Nappe de Passos; 20-Transporte tectônico principal da Nappe de Passos; 21-Cidades; 22- Seção geológica da figura 5 a.

Figure 3 - Litho-tectonic map of the northern sector of the Externai Allochthonous Domain, where roman numbers indicate number of thrust sheet: 1- Bambuí group (autochthonous); 2-Quartzites and phyllites (thrust sheet I); 3-Greenstone-belt sequence (thrust sheet II); 4-Deformed granitoid rocks (thrust sheet II); 5Turbiditic sequence, medium facies (thrust sheet III); 6- Turbiditic sequence, distai facies (thrust sheet III); 7- Chromite-bearing ultramafic schists (thrust sheet IV); 8-Meta-conglomerates predominant (thrust sheet V); 9-Recrystallized quartzites predominant (thrust sheet VI); 10-Orthogneisses (thrust sheet I); 11- Passos Nappe; 12-Major thrust faults; 13-Subordinate thrust faults; 14-Sole thrust of Passos Nappe; 15- Synformal axial trace; 16-Antiformal axial trace; 17-Normal fault; 18-Indiscriminated subvertical fault; 19-Lateral ramp of Passos Nappe; 20-Tectonic vergence of Passos Nappe; 21- Localities; 22-Geological section of figure $5 \mathrm{a}$. 


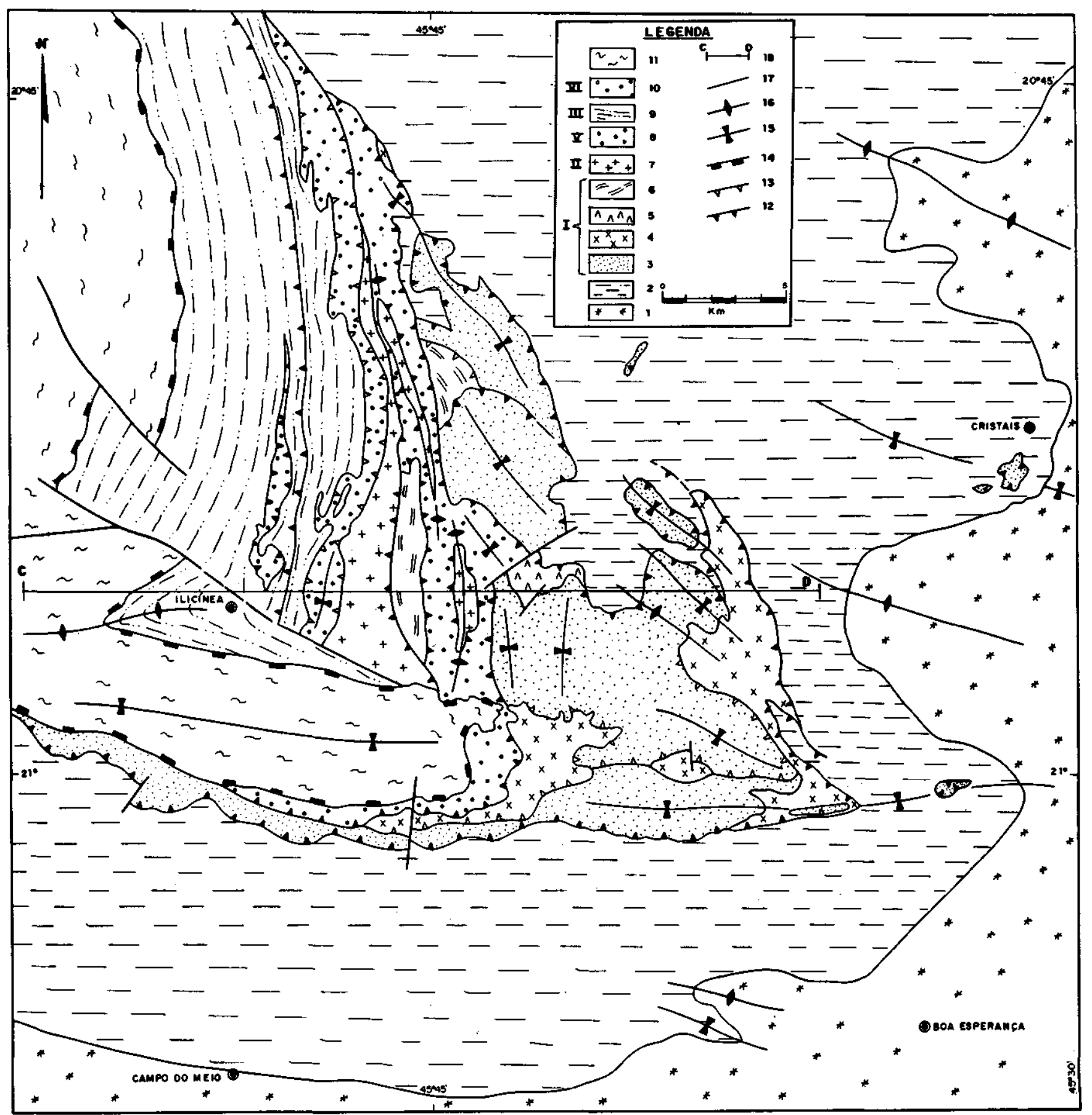

Figura 4 - Mapa litotectônico do setor sul do Domínio Alóctone Externo, onde algarismos romanos indicam o número da escama tectônica correspondente, l- Embasamento autóctone indiviso; 2- Grupo Bambui (autóctone); 3-Quartzitos efilitos (Escama I); 4- Ortognaisses (Escama I); 5-Xistos ultramáficos cromitíferos (Escama IV); 6-Grupo Bambui (alóctone); 7'-Granitóides foliados (Escama U); 8-Predominância de metaconglomerados (Escama V); 9-Sequência turbidítica (Escama III); 10- Predominância de quartzitos muito recrístalizados (Escama VI); 11- Nappe de Passos; 12-Falha de empurrão principal; 13- Falha de empurrão subordinada; 14- Empurrão basal da Nappe de Passos; 15- Traço axial de sinformal; 16- Traço axial de antiformal; 17- Falha subvertical indiscriminada; 18- Seção geológica da figura 5 b.

Figure 4 - Litho-tectonic map of the southern sector of the Externai Allochthonous Domain, where roman numbers indicate number of thrust sheet: 1-Autochthonous basement; 2- Bambuí group (autochthonous); 3-Quartzites and phyllites (thrust sheet I); 4-Orthogneisses (thrust sheet I); 5- Chromite bearing ultramafic schists (thrust sheet IV); 6- Bambuí group (allochthonous); 7-Deformed granitoid rocks (thrust sheet II); 8-Meta-conglomerates predominant (thrust sheet V); 9-Turbiditic sequence (thrust sheet III); 10-Recrystallized quartzites predominant (thrust sheet VI); 11-Passos Nappe; 12- Major thrust faults; 13-Subordinated thrust faults; 14-Sole thrust of Passos Nappe; 15-Synformal axial trace; 16-Antiformal axial trace; 17-Indiscriminated subvertical fault; 18Geological section of figure $5 \mathrm{~b}$. 
a)
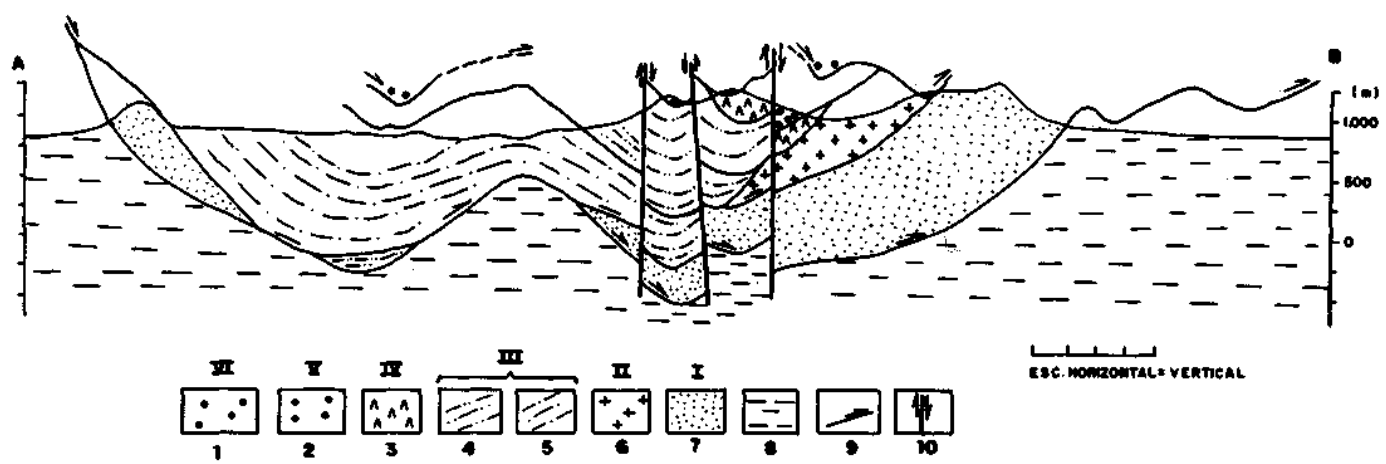

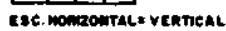

b)
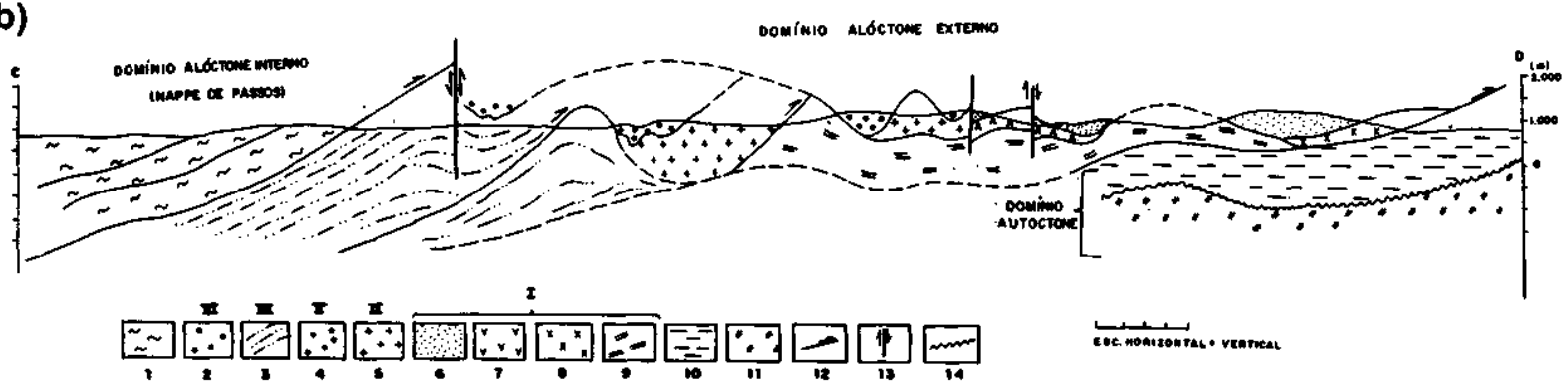

Figura 5 - a) Seção geológica no setor norte do Domínio Externo Alóctone, onde algarismos romanos correspondem ao número da escama tectônica correspondente, l-Predominância de quartzitos muito recristalizados (Escama VI); 2-Predominância de metaconglomerados (Escama V); 3-Xistos ultramáficos cromitíferos (Escama IV); 4- Sequência turbidítica, facies média (Escama III); 5- Sequência turbidítica, facies distai (escama III); 6- Granitóides foliados (Escama II); 7- Quartzitos efilitos (Escama I); 8-Grupo Bambuí autóctone; 9- Falha de empurrão; 10- Falha subvertical. b) Seção geológica do setor sul do Domínio Alóctone Externo: l- Nappe de Passos; 2- Predominância de quartzitos muito recristalizados (Escama VI); 3- Sequência turbidítica (Escama III); 4- Predominância de metaconglomerados (Escama V); 5- Granitóides foliados (Escama II); 6- Quartzitos efilitos (Escama l); 7- Xistos ultramáficos cromitíferos (Escama IV); 8-Ortognaisses (Escama I); 9- Grupo Bambui (alóctone); 10Grupo Bambui (autóctone); 11- Embasamento autóctone indiviso; 12- Falha de empurrão; 13- Falha subvertical. Figure 5 - a)- Geological section of the southern sector of the Externai Allochthonous Domain, where roman numbers indicate number of thrust sheet: 1-Recrystallized quartzites predominant (thrust sheet VI); 2-Meta-conglomerates predominant (thrust sheet V); 3-Chromite-bearing ultramafic schists (thrust sheet IV); 4-Turbiditic sequence, médium facies (thrust sheet III); 5-Turbiditic sequence, distai facies (thrust sheet III); 6-Deformed granitoid rocks (thrust sheet II); 7- Quartzites and phyllites (thrust sheet I); 8- Bambuí group (autochthonous); 10 Thrust fault; 11- subvertical fault. b) Geological section of the southem sector of Externai allochthonous Domain: 1- Passos Nappe; 2-Recrystallized quartzites predominant (thrust sheet VI); $\mathrm{S}^{\wedge}$ Turbiditic sequence (thrust sheet III); 4-Meta-conglomerates predominant (thrust sheet V); 5-Deformed granitoid rocks (thrust sheet II); 6- Quartzites and phyllites (thrust sheet I); 4- Orthognaisses (thrust sheet I); 7- Chromite-bearing ultramafic schists (thrust sheet IV); 8- Orthogneisses (thrust sheet I); 9- Bambuí group (allochthonous); 10-Bambuí group (autochthonous); 11-Autochthonous basement; 12-Thrust fault; 13- Subvertical fault.

ESCAMA IV Esta escama tem uma área de exposição limitada, porém de grande relevância econômica, pela sua associação ultramáfica cromitífera, e tectônica, pelas suas afinidades alpinotípicas. Na área a sul de Piumhi, seu padrão de afloramento é complicado pela superposição de falhas tardias em blocos, de direção N e NE, sobre o conjunto de empurrões subhorizontais. Aflora de forma descontínua na porção basal das sinformas das serras da Gabiroba e do Lavapés, nas fraldas da Serra do Lavapés e ao longo da vertente oriental da Serra da Gabiroba. Para sul, é recoberto pelas escamas superiores, somente reaparecendo sob o flanco oposto da Nappe de Passos, na base da sinforma da Serra do Tabuleiro, a norte de Carmo do Rio Claro (Heilbron et al. 1987), empurrado diretamente sobre os metaconglomerados Samburá, pertencentes ao Grupo Bambuí. Sua litologia é uma predominância de talco xistos e serpentinitos contendo corpos irregulares de cromitito em formas irregulares, de sigmóide (Fig. 6) ou de elipsóides prolatos de cromitito puro ou com matriz de talco-serpentina.

ESCAMA $V$ Esta escama tem sua ocorrência sempre em porções superiores, tendo como representantes típicos meta- conglomerados quartzíticos muito deformados, com seixos majoritariamente de quartzo em matriz quartzo-sericítica. Seixos de jaspe avermelhado e de metapelito negro, extremamente estirados, são comuns, sendo mais raros os de formação ferrífera. A unidade constitui uma associação com variações granulométricas laterais e verticais bruscas, que vão de metapelitos, metarenitos micáceos e metaconglomerados com seixos prolatos de até $1 \mathrm{~m}$ de diâmetro aparente, exagerados pelo estiramento tectônico. Característica é a alternância centimétrica a decimétrica de leitos esverdeados (devido à sericita esverdeada) e cinzentos (devido a opacos finos), independentemente da granulometria. Localmente, na base ocorre formação ferrífera laminada associada a filhos grafitosos manganesíferos e metarenito hematítico.

ESCAMA VI Esta escama, de colocação tardia, recobre todas as demais escamas sob a forma de vários klippen (Figs. 3 e 4), truncando seus contatos, subparalelos à foliação $\mathrm{Si}$, e mesmo dobras pós- $\mathrm{D}_{1}$. Apresenta a mesma litologia da escama I, tipificada pelos grânulo-quartzitos, porém com maior grau de recristalização. 


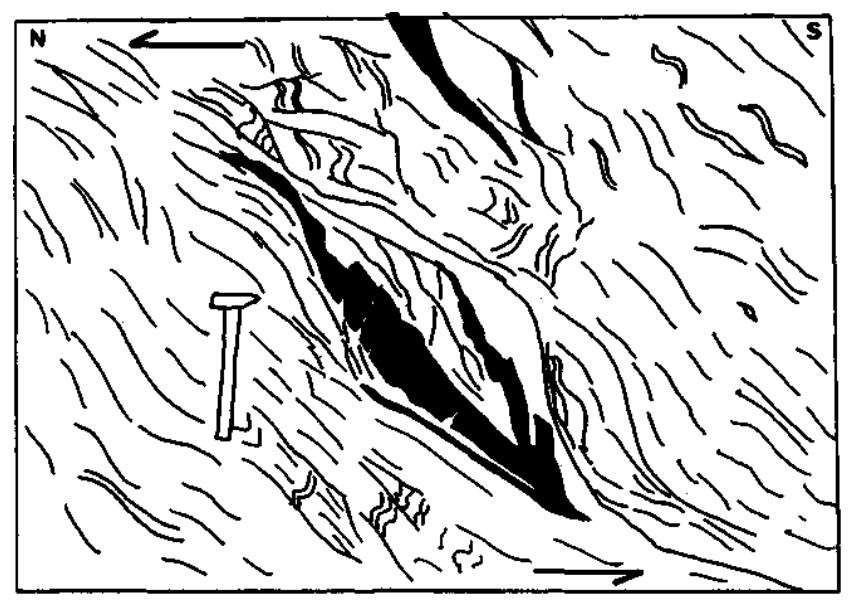

Figura 6 - Exemplo de indicador cinemática do transporte tectônico para norte: corpos de cromitito imersos em talcoserpentina xisto da escama IV, com padrão sigmóide, associados a sigmóides de foliação SI. Desenhado sobre fotografia.

Figure 6 - Example of kinematic indicator of the northwards tectonic transport: chromitite bodies within talc-serpentine schists from thrust sheet IV, with sigmoid shape.associated to foliation sigmoids. Drawn from photograph.

\section{EVOLUÇÃO DEFORMACIONAL DO DAE E INDI- CADORES CINEMÁTICOS Aspectos Geométricos} da Deformação Apesar do Domínio Alóctone Externo ser caracterizado por um complexo de imbricação de escamas de empurrão separadas por superfícies discretas de deslizamento, que frequentemente incluem feições rúpteis, individualmente as escamas apresentam um fabric interno com grande heterogeneidade de strain, porém essencialmente dúctil. O quartzo frequentemente mostra intensa recristalização dinâmica, resultando em texturas tipicamente miloníticas.

O exame meso e microscópico das rochas deste domínio coloca em evidência um contraste de estilo entre as estruturas e texturas formadas na primeira fase de deformação $\left(D_{1}\right)$ e nas que a esta se superpõem. De natureza sin-metamórfica, $\mathrm{D}_{1}$ se constitui na "deformação principal" que afetou todo o conjunto de maneira dúctil e penetrativa, embora com intensidade bastante heterogénea. As deformações que se superpõem à anisotropia planar e linear decorrente da deformação principal serão, para fins de descrição, coletivamente denominadas de "deformação pós- $\mathrm{D}_{1}$ ".

A DEFORMAÇÃO PRINCIPAL $\left(D_{l}\right)$ A primeira fase de deformação $\left(\mathrm{D}_{1}\right)$ teve sua evolução geneticamente relacionada a um cisalhamento de baixo ângulo em condições de facies xisto verde, na zona da clorita. Como resultado do achatamento que frequentemente foi intenso houve a geração da foliação penetrativa do conjunto (clivagem ardosiana $S_{1}$ ) com variedades morfológicas. Associadas ao cisalhamento dúctil heterogéneo ocorrem lineações de estiramento contidas em $\mathrm{S}_{1}$ e, muito subordinadamente, dobras com clivagem plano axial $\left(\mathrm{S}_{1}\right)$ e lineação de interseção entre $\mathrm{S}_{0}$ e $\mathrm{S}_{1}$.

Dobras $D_{1}$ ea Lineação de Interseção Foram observadas apenas duas megadobras com clivagem ardosiana S 1 no plano axial: a sinformal aberta que constiui o klippe da Serra da Tromenta; e uma dobra em "Z" (olhando para Norte) na Serra do Chapadão (Fig. 3). São dobras abertas, tendendo a isópacas, com ângulos interflancos em torno de $90^{\circ}$. $\mathrm{Na}$ sinformal da Serra da Tromenta é clara a disposição em leque da clivagem: no flanco suave, que mergulha para SW, a clivagem é íngreme enquanto que no flanco íngreme a clivagem apresenta mergulho suave. No caso da dobra assimétrica, apenas no flanco curto a foliação faz ângulo significativo com a estratificação sedimentar, ocasionando maior evidência da lineação de interseção entre estes dois planos.

A Foliação $S_{1}$ Exceto na proximidade de raras dobras observadas da primeira fase, a clivagem $S_{1}$ apresenta-se subparalela ou fazendo ângulos de no máximo $20^{\circ}$ com o acamamento sedimentar. Como é de se esperar em um regime de cisalhamento, observa-se que quanto mais intensa a deformação, maior é o paralelismo entre $\mathrm{S}_{0}$ e $\mathrm{S}_{1}$. A morfologia da foliação $S_{1}$ varia muito conforme a litologia e a intensidade do cisalhamento associado. Em metapelitos, a $\mathrm{S}_{1}$ é uma típica clivagem ardosiana. Em deformação mais baixa e em charneiras de dobras $\mathrm{D}_{1}$ (onde talvez haja participação maior de deformação por cisalhamento puro), desenvolve-se com disposição planar/paralela, oblíqua a $\mathrm{S}_{0}$, com importantes efeitos de refração em interfaces metapelito/metapsamito. A dissolução preferencial do quartzo em planos concentrados, e consequente concentração residual de mica, opacos e outros minerais tem importante papel na formação da clivagem neste contexto. Em condições mais intensas de deformação a clivagem tende a se tornar subparalela a $\mathrm{S}_{0}$ e adquire aspecto anastomosado, com desenvolvimento de agregados micáceos sigmoidais (mica fisK).

É nos metarenitos quartzíticos puros que melhor se pode observar a deformação cristalina, pois originalmente mais de $90 \%$ de seu arcabouço é formado por grãos e grânulos detríticos de quartzo monocristalino bem arredondado e selecionado, sem matriz. Com a deformação, tiveram seu contorno relativamente bem preservado, exceto nos estágios avançados de recristalização dinâmica. Conforme aumenta a intensidade da deformação neste litotipo, observa-se uma sucessão de estágios texturais, decorrentes da relativa importância de diferentes mecanismos de deformação intra e intercristalina, que determinam a morfologia da foliação $S_{1}$ :

- Dissolução por pressão e precipitação sintaxial do quartzo na sombra de pressão do grão, ou em forma de veios extensionais; leve orientação preferencial de forma de grão (shape preferred orientatiori); nenhuma orientação ótica (latticepreferred orientation, Passchier \& Trouw, in press).

- dissolução por pressão acompanhada de leve extinção ondulante, evidenciando deformação cristalo-plástica; maior grau de orientação preferencial de forma de grão;

- extinção ondulante mais forte, acompanhada achatamento dos grãos e de recristalização dinâmica na borda (protomilonito);

- formação de zonas de alta deformação subparalelas ao plano de cisalhamento, recristalizadas em grãos poligonais muito finos, que contornam grãos de aspecto alongado (porfiroclastos) com extinção ondulante, conferindo à rocha uma textura fortemente lenticular (milonito).

- forte recristalização dinâmica com diminuição do tamanho do grão e formação de contatos serrilhados; descaracterização total dos grãos detríticos originais; forte orientação de forma e ótica do quartzo; desenvolvimento de contatos de sub-grãos oblíquos à orientação de forma, coerentes com o padrão de foliações S-C (ultramilonito). 
A Lineação de estiramento Seixos, grânulos e outros objetos fortemente alongados definem a lineação de estiramento contida na foliação $\mathrm{S}_{1}$. Mostra forte variação morfológica de acordo com a intensidade da deformação, sendo, no entanto, penetrativa em todas as escamas. Nos metarenitos e metaconglomerados se torna bem visível, com forte estiramento dos grânulos e seixos. Nas rochas pelíticas e em parte da sequência greenstone, traduz-se por agregados microcristalinos alongados paralelos a uma lineação de crenulação muito apertada. Em zonas de deformação rúptil aparecem como estrias em superfícies de deslizamento.

DEFORMAÇÕES PÓS- $D_{1}$ Dobras de duas orientações e um complexo arranjo de cavalgamentos se superpõem ao conjunto $\mathrm{S}_{1} / \mathrm{L}_{1}$. Falhas conjugadas e kinks completam o padrão estrutural pós- $\mathrm{D}_{1}$. Não há formação de foliação penetrativa, apenas localmente pode-se observar uma clivagem de crenulação espaçada ou planos de kink. Nas zonas de empurrão associadas às dobras, há a reativação ou simples rotação da foliação $S_{1}$. Na maioria das vezes os empurrões truncam o conjunto $\mathrm{S}_{1} / \mathrm{L}_{1}$ e não raro truncam as dobras N-S pós- $\mathrm{D}_{1}$.

Dobras Pós- $D_{1}$ Na grande maioria dos afloramentos é possível a observação de uma ou duas direções de dobras suaves a abertas sobre a foliação $S_{1}$. Fraturas e falhas subverticais se associam com frequência à superfície axial destas dobras.

Estas duas gerações de dobras sobre $\mathrm{S}_{1}$ apresentam ampla dispersão em suas orientações. Um conjunto predominante de dobras tem eixos de caimento suave N-S, e outro tem eixos de caimento suave entre E-W e NW-SE, ambos com superfícies axiais íngremes. $\mathrm{O}$ ângulo médio entre a direção dos respectivos eixos é de $71^{\circ}$.

São estruturas pós-auge metamórfico, pois não criam foliação plano-axial e as distorções nos retículos cristalinos não apresentam sinais de recuperação, indicativos da baixa temperatura durante e após a deformação.

As duas direções de dobras mostram localmente padrão de interseção tipo domos e bacias. No setor a norte da Rampa Lateral de Capitólio, predominam as dobras com eixo N-S (Fig. 3), e na porção mais a sudeste (Serra da Boa Esperança) as de direção ESE-WNW também são expressivas (Fig. 4).

Falhas Pós- $D_{1}$ Além de falhas íngremes com movimento subvertical, especialmente desenvolvidas a sul de Piumhi, e de falhas subverticais de movimentação indeterminada, foi identificado um sistema de falhas transcorrentes conjugadas de alto ângulo, com resolução de compressão leste-oeste, associado à colocação da Nappe de Passos, que corta o conjunto $\mathrm{S}_{1} / \mathrm{L}_{1}$.

Indicadores cinemáticos As rochas do DAE possuem abundantes feições indicadoras da direção de transporte tectônico, principalmente lineações de estiramento, especialmente visíveis nos metarenitos grossos e nos metaconglomerados. Como indicadores do sentido de transporte tectônico, foram observados principalmente sigmóides de foliação (Fig. 6), conjuntos de foliações S-C, peixes de mica, shear bands e dobras assimétricas (Fig. 7), dentre outras.

Foi realizado um estudo da orientação e frequência de incidência, através de diagramas estereográficos (Rede de Schmidt) de 479 medidas de lineações de estiramento, cole- tadas em todas as escamas tectônicas acima definidas, inclusive no Grupo Bambuí (autóctone).

Com base nos levantamentos de Valeriano (1992) e de Simões (1995), a Nappe de Passos mostra uma trajetória de lineações de estiramento variando entre as direções NW, na sua porção ocidental, e EW, na porção frontal (Fig. 8).

De modo geral, o conjunto das medidas mostra duas fortes concentrações: uma com rumo máximo de N170, variando entre N150 e N225, e outra com máximo de N290, esta última claramente relacionada à movimentação da Nappe de Passos (Simões \& Valeriano 1990, Schrank et al 1990), sendo inclusive muito mais presente a sul da Rampa Lateral de Capitólio, ou seja, na área sob influência direta da Nappe de Passos.

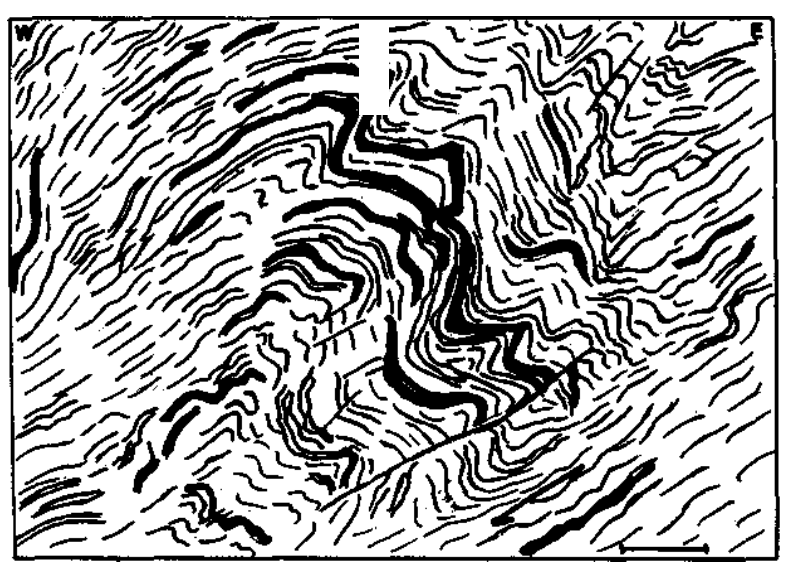

Figura 7 - Exemplo de indicador cinemática do transporte tectônico para ESE: dobras assimétricas associadas a falhas de empurrão afetando S1//SO, em quartzo-filitos sericíticos da escama V. Barra de escala $=5 \mathrm{~cm}$. Desenhado sobre fotografia.

Figure 7 - Example of kinematic indicator of the southeastward tectonic transport: asymetric folds associated to thrust faults deforming $\mathrm{S} 1 / \mathrm{SO}$, in sericitic quartz phyllites from thrust sheet $V$. Scale bar $=5 \mathrm{~cm}$. Drawn from photograph.

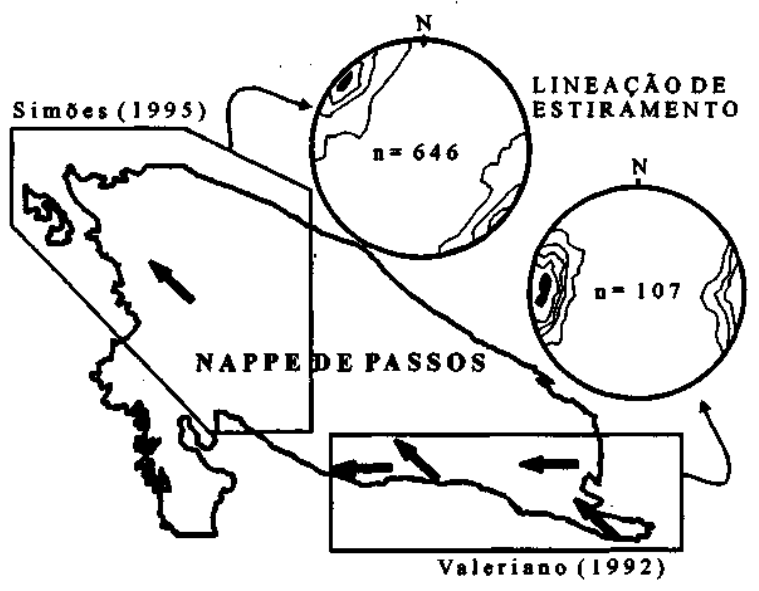

Figura 8 - Distribuição da lineação de estiramento na Nappe de Passos, variando entre máximos em torno de $N W$ e EW (Valeriano 1992, Simões 1995). Estereogramas (hemisfério inferior) com contornos de 0-5-10-15\% (Simões 1995) e de 0,25-5-10-20\% (Valeriano 1992) por 1\% de área. Figure 8 - Distribution of the stretching lineation in the Passos Nappe, with plunge direction varying between NW and EW (Valeriano 1992, Simões 1995). Lower hemisphere stereoplots with contours of 0-5-10-15\% (Simõ es 1995 ) and of $0.25-5-10-20 \%$, per $1 \%$ área (Valeriano 1992). 
Todas as escamas mostram estes dois conjuntos de direção de lineação, porém dependendo da unidade tectônica considerada, a incidência relativa desses dois máximos de concentração é variável: nas escamas I e VI, respectivamente basal e superior do DAE, as duas direções são frequentes (Figs. 9a 9c), ao passo que nas escamas intermediárias, de II a V (Fig. 9b), a lineação N-S é especialmente marcante, embora também existam registros da lineação WNW.

Observa-se, no campo, uma íntima associação entre a lineação de estiramento N-S e indicadores cinemáticos com movimentação de topo para o norte, tais como peixes de mica, shear bands, foliações S-C e sigmóides definidos por objetos deformados (Fig. 6) e pela foliação $\mathrm{S}_{1}$. Por outro lado, as lineações de direção WNW mostram associação com indicadores de movimentação com topo vergente para ESE, tais como dobras assimétricas sobre o conjunto $\mathrm{S}_{0} / \mathrm{S}_{1}$ (Fig. 7), estrias em planos de falhas discretos, e efeito de rotação da lineação de estiramento mais antiga (N-S) para a direção ENE, próximo aos contatos das escamas I e VI (Fig. 10).

As rochas do Grupo Bambuí (Domínio Autóctone) não mostram registro do transporte téctônico vergente para norte (Fig. 9d), sendo a área a sul da Nappe de Passos (Carmo do Rio Claro) a que melhor adquiriu a lineação N290. Em con- traste, na área a norte da Rampa Lateral de Capitólio, não diretamente recoberta pela Nappe de Passos, os metaconglomerados Samburá não foram deformados a ponto de gerar uma lineação de estiramento visível.

DISCUSSÃO A interpretação do quadro descrito acima é de que a lineação N290, e estruturas associadas, são contemporâneas ao transporte WNW-ESE brasiliano da Nappe de Passos, e que foi o único episódio a deformar as rochas do Grupo Bambuí autóctone (Magalhães et al 1989), como pode ser visto na Figura 9d. Esta tectônica é superposta aofabríc planar/linear N-S, que é reliquiar com relação à compressão WNW-ESE brasiliana, constituindo o registro de uma compressão pretérita importante, pois envolve uma escama de rochas ultramáficas contendo corpos cromitíferos de características alpinotípicas (Schrank \& Silva 1993). Estefabric pretérito, vergente para norte, foi trazido passivamente nas rochas do DAE, sobre as rochas do Grupo Bambuí.

Não por acaso, as escamas I e VI registraram melhor o transporte téctônico para ESE, pois acompanham respectivamente o empurrão basal do DAE e a zona sob a influência mais próxima do empurrão basal da Nappe de Passos.

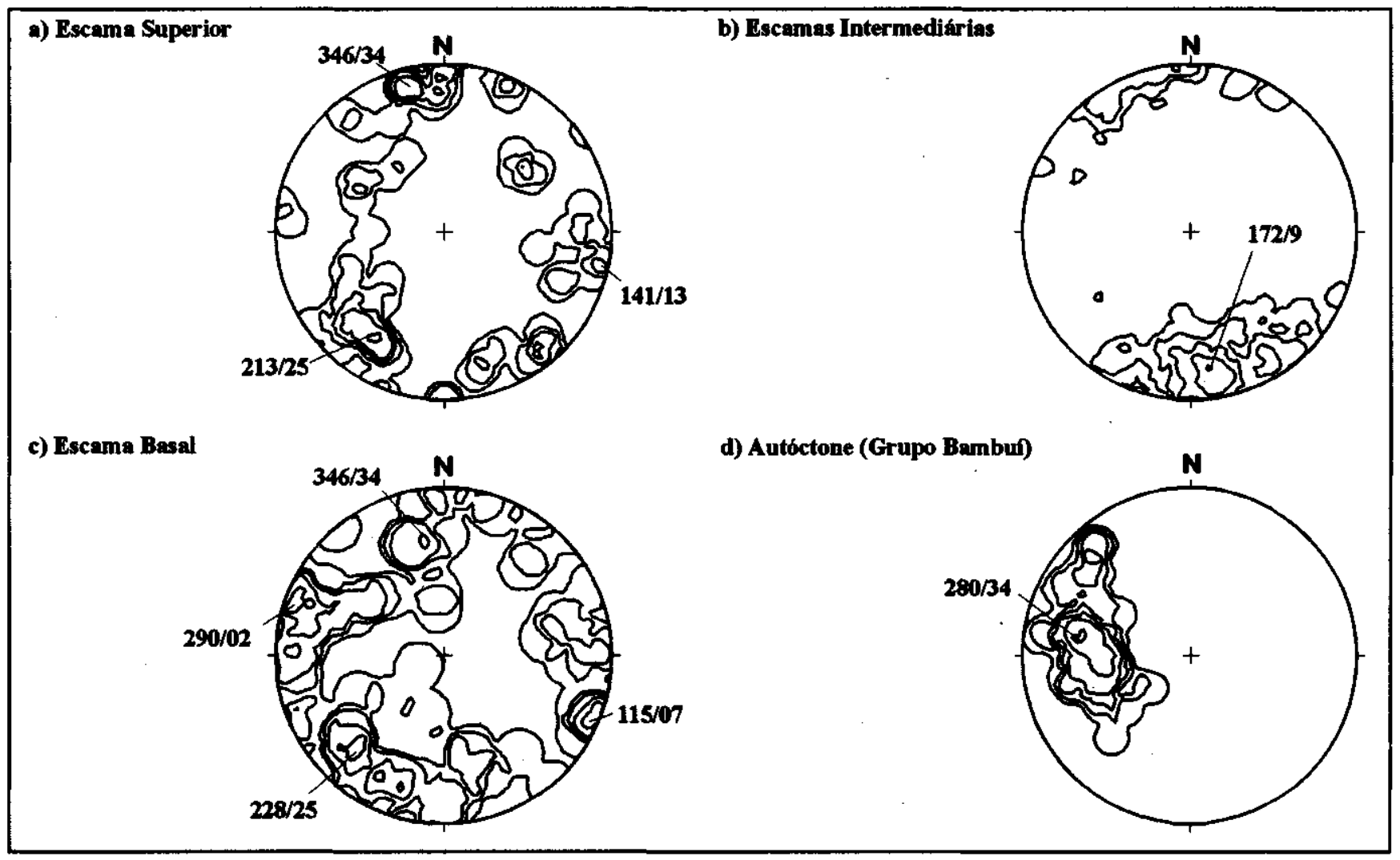

Figura 9 - Comparação da distribuição das lineações de estiramento. Nota-se a maior frequência da orientação para ESE nas escamas I (basal) e VI (superior), a menor intensidade desta tectônica nas escamas II, III, IV e V; e a inexistência da lineação para $N$ nas rochas do Grupo Bambui (Autóctone).a) Escama VI (n=78): isolinhas de 1,5-3 - 4,5 - 6,5 e 9\% por 1\% de área; b) Escamas U, III, IV e V(n=305): isolinhas de 1,5-2,5-4- 6,5 e 8\% por 1\% de área; c) Escama I (n=64): isolinhas de 1,5 - 2,5 -4-6,5 e 9\% por 1\% de área; d) Domínio Autóctone (n-47): isolinhas de 2,5-4- 6,5-8,5-12,5 e 19\% por 1\% de área. Figure 9 - Comparison of the orientation distribution of the stretching lineations. The greater frequence of ESE lineations in thrusts sheets I (basal) and VI (superior); the less intense ESE lineation in thrust sheets II to V; and the inexistence of the N-S lineation in the Bambuí group rocks (autochthonous) are observed. a) Thrust sheet VI (n=78): contours of $1.5-3-4.5-6.5$ and $9 \%$ per $1 \%$ área; b) Thrust sheets II, III, IV and V ( $\mathrm{n}=305)$ : contours $1.5-2.5-4-6.5$ and $8 \%$ per $1 \%$ área; c) Thrust sheet I (n=64): contours 1.5 - 2.5 - 4 - 6.5 and 9\% per 1\% área; d) Autochthonous Domain (n=47): contours $2.5-4-6.5-8.5-12.5$ and $19 \%$ per $1 \%$ área. 


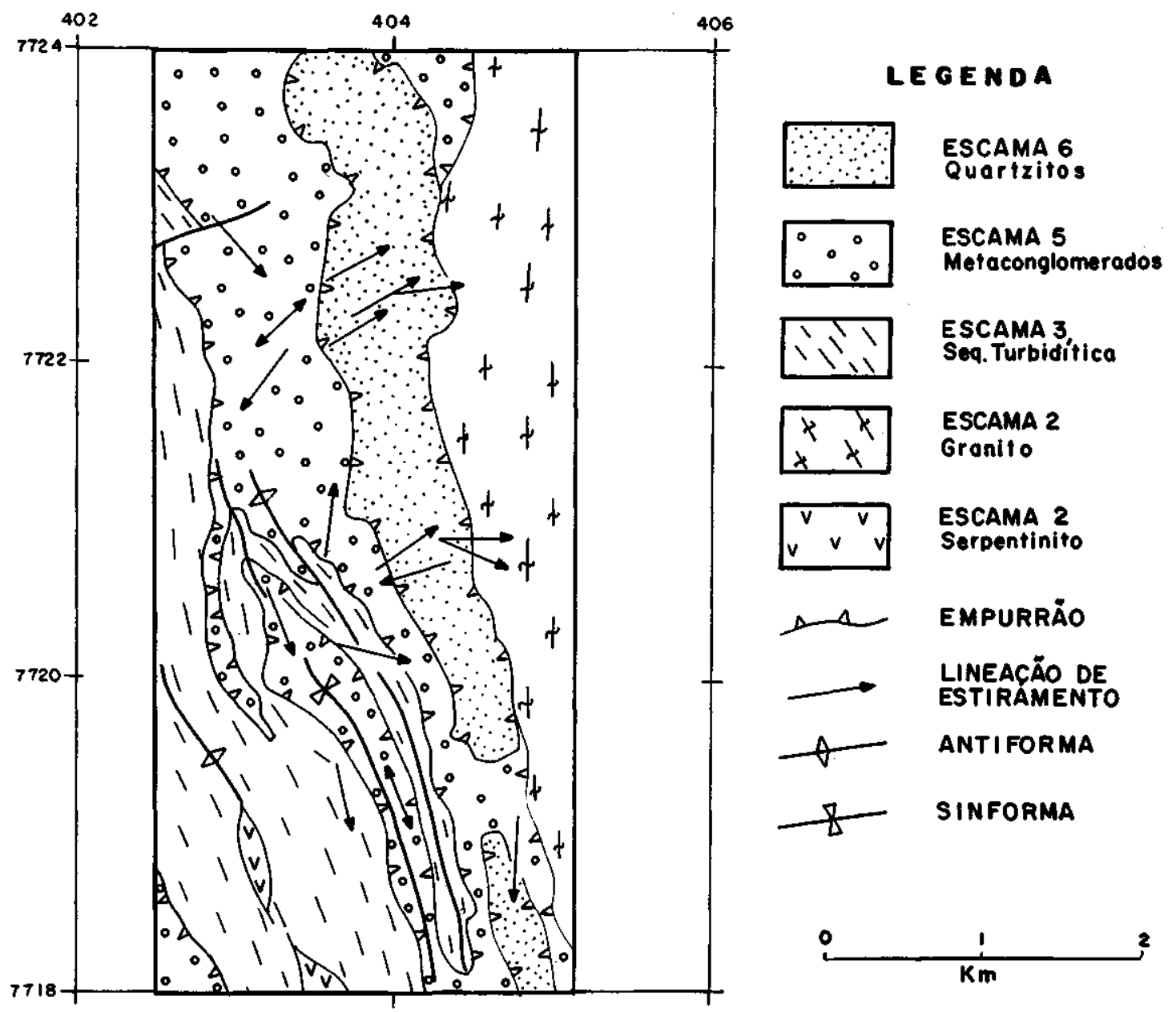

Figura 10 - Exemplo de rotação progressiva da lineação de estiramento (caimentos $<30^{\circ}$ ) mais antiga (próximo de $N$-S), para a direção ENE, em função da aproximação do contato com a escama VI. Serra da Gabiroba 14 Km a sul de Piumhi.

Figure 10 - Example of progressive rotation of the older (near N-S) stretching lineation (plunges $<30$ ), in the proximitíes of the contact with thrust sheet VI. Gabiroba Range 14 km south of Piumhi town.

\section{O caráter pré-brasiliano do transporte tectônico} para norte $\mathrm{O}$ forte fabric linear $\mathrm{N}-\mathrm{S}$, produto do empilhamento tectônico para Norte mais antigo (Schrank et al 1990), é interpretado como pré-brasiliano, tendo como base as seguintes considerações:

- na Nappe de Passos, onde é melhor registrada a história metamórfico-deformacional da Faixa Brasília meridional (Simões et al. 1988, Simões \& Valeriano 1990, Simões 1995), não se observam vestígios do transporte tectônico para o norte (Fig. 8), restrito ao DAE. Mesmo na cobertura do Domínio Autóctone, Grupo Bambuí, que por ser a unidade litoestratigráfica mais nova, é um marcador da deformação brasiliana, 0 transporte tectônico para norte não foi impresso (Alkmin et al. 1989).

- A compressão E-W brasiliana, na Faixa Brasília meridional, não afetou termicamente o Domínio Autóctone, especialmente seu embasamento cratônico (Teixeira 1982, 1985, Valeriano 1992), a ponto de abrir os sistemas isotópicos K-Ar de biotita e mica-branca. O resfriamento pós-orogênico, dado por datações K-Ar na Nappe de Passos e no DAE, situa-se no intervalo entre 580 e 640 Ma. (Machado Filho et al. 1983, Correia 1986, Valeriano 1992), ao passo que na infra-estrutura do Domínio Autóctone é pré-brasiliano, com idades de 1 .7-1.8 Ga, no embasamento do CSF (Teixeira 1985), e pré-1.0 Ga no Complexo Campos Gerais (Teixeira \& Akimoto 1989).
Hipóteses possíveis para a idade do transporte tectônico para norte, registrado apenas no DAE, podem ser especuladas:

a- Transamazônico: em uma analogia com o quadro tectônico do Quadrilátero Ferrífero, o evento compressivo mais antigo verificado no DAE poderia ser atribuído ao Transamazônico, que é o evento pré-brasiliano mais recente naquela área, tendo sido inclusive apontados vestígios de transporte tectônico para norte entre as fases de deformação mais antigas (Ladeira 1985).

b- Evento Mesoproterozóico: tendo como referência os terrenos mais a sul, ou seja, de onde partiu a aloctonia dirigida para norte, existem indícios geocronológicos de eventos de metamorfismo e granitogênese no Mesoproterozóico, por volta de $1.4 \mathrm{Ga}$., em terrenos da Faixa Ribeira no sudoeste mineiro e no Estado de São Paulo (Tassinari et al. 1988, Tassinari \& Campos Neto 1988);

c- Brasiliano precoce: em princípio, os movimentos tectônicos para norte poderiam ser ainda atribuídos a uma fase compressiva precoce ligada ao evento Brasiliano, uma vez que faltam dados de geocronologia isotópica que excluam a possibilidade de uma idade neoproterozóica. Entretanto, não se encontram referências destes movimentos tectônicos na literatura sobre o restante da Faixa Brasília, o que pode ser uma peculiaridade do seu segmento meridional. Por outro lado, caso esta possibilidade seja comprovada futuramente, é dificil 
compatibilizar duas vergências ortogonais em uma mesma evolução orogênica, sendo aí mais plausível a redefinição do quadro tectônico regional com duas orogêneses neoproterozóicas superpostas, produtos de configurações geodinâmicas distintas.

O empilhamento tectônico brasiliano A norte da rampa lateral de Capitólio (Fig. 3) as escamas I e VI, respectivamente basal e superior, com a mesma constituição litológica, foram colocadas durante a compressão E-W brasiliana, imprimindo ao DAE a conformação de um duplex (Boyer \& Elliot 1982) brasiliano formado por rochas antigas que trouxeram consigo um forte fabric deformacional interno vergente para norte, relíquia de um evento compressivo pretérito.

O DAE, em um estágio de construção orogênica por imbricação tectônica cedo-Brasiliano, serviu como área fonte para os metaconglomerados Samburá, que ocorrem superpostos ao Sub-grupo Paraopeba, e que contêm seixos provenientes dos calcários desta unidade e das rochas do DAE. No estágio final desta colisão brasiliana, deu-se o empilhamento tectônico atualmente verificado, com o empurrão do DAE sobre o Grupo Bambuí e da Nappe de Passos sobre ambos.

CONSIDERAÇÕES FINAIS As relações estruturais discutidas acima indicam que o DAE constitui um maciço com relação à tectônica brasiliana, ou seja, uma unidade alóctone estruturada previamente em um evento compressivo mais antigo, envolvido na imbricação brasiliana. A intensa aloctonia desta unidade, colocada por empurrões rasos sobre $\mathrm{o}$ autóctone, caracteriza a área do DAE como zona áeforeland thrust-foldbelt, não devendo ser cartografada tectonicamente como pertencente ao Cráton do São Francisco (Valeriano 1993).

O conglomerado Samburá, que se mostra sobrejacente ao Sub-Grupo Paraopeba, como observado na área a norte de Cristais (Valeriano 1992), constitui-se num depósito sin-compressional com referência aos cavalgamentos brasilianos, pois seus seixos são constituídos por rochas do DAE e do Subgrupo Paraopeba, produtos da erosão da área montanhosa formada pela frente alóctone em um momento precoce da compressão brasiliana. Com a continuação do avanço da frente alóctone brasiliana, os metaconglomerados Samburá e o restante do Grupo Bambuí foram finalmente recobertos tectonicamente pelo DAE, estágio este que inclui também a colocação da Nappe de Passos sobre todas as demais unidades tectônicas.

Agradecimentos Os trabalhos de campo foram executados com recursos do CNPq (Processos 406826/89-7 e 403108/90-0), da UNESP e da UERJ, através de trabalhos curriculares de campo, que contaram com o esforço e dedicação de colegas professores e de inúmeros alunos de graduação das duas escolas. Os autores agradecem ainda a atenciosa leitura crítica e as valiosas sugestões do Prof. Benjamim B. Brito Neves (IG-USP), que muito melhoraram o manuscrito original, e ao Sr. Evangelista Caputo pela execução dos desenhos.

\section{REFERÊNCIAS}

ALKMIN, F. F.; BACELAR, L. A. P.; OLIVEIRA, P. M.; MAGALHÃES, P. M. 1989. Arcabouço estrutural da porção sul da Bacia do São Francisco. In SIMP. GEOL. MINAS GERAIS, 5, Belo Horizonte 1985. Anais... SBG, Boletim 5, pp 289-283.

ALMEIDA, F. F. M. de. 1977.0 Cráton do São Francisco. Revista Brasileira de Geociências, 7(4): 349-364.

ARAÚJO, J. B. 1943. Cromita da Fazenda Caxambu, Piui. Boletim do Laboratório de Produção Mineral, DNPM, Rio de Janeiro, 23: 71-95.

BARBOSA, O. \& LACOURT, F. 1940. Cromita em Piui. Mineração e Metalurgia, Rio de Janeiro, 5(25):39-43.

BARBOSA, O.; BRAUN, O. P. G.; DYER, R. C.; CUNHA, C. A. B. R. 1970. Geologia da Região do Triângulo Mineiro. Boletim da Divisão de Fomento da Produção Mineral, DNPM, Boi. 136140 p.

BOYER, S. E. \& ELLIOTT, D. 1982. Thrust Systems. American Association of Petroleum Geologists Bulletin, 66(9): 1196-1230.

BRANCO, J. J. R. 1956. Conglomerado do Samburá, MG. Anais da Academia Brasileira de Ciências, 28:295-302.

CAVALCANTE, J.; CUNHA, H.C.S.; CHIEREGATTI, L.A.; KAEFER, L.Q.; ROCHA, J.M.; DAITX, E.C.; COUTINHO, M.G.N.; YAMAMOTO, K.; DRUMOND, J.; ROSA, D.B. \& RAMALHO, R. 1979. Projeto Sapucaí, estados de São Paulo, Rio de Janeiro e Minas Gerais. Brasília, DNPM/CPRM. 229p. (Relatório final de geologia).

DARDENNE, M. A. 1978. Síntese sobre a estratigrafia do Grupo Bambuí no Brasil Central. In: CONGR. BRAS. GEOL., 30. Recife 1978. Anais... Recife, SBG, v.2, p. 597-602.

DOMINGUEZ, J. M. L. \& MISI, A. 1993. O Cráton do São Francisco. Trabalhos apresentados na reunião preparatória do II Simpósio sobre o Cráton do São Francisco. Salvador, SBG/SGM/CNPq, 215 p.

FRITZSONS JR. O.; BIONDI, J. C.; CHABAN, N. 1980. Geologia da região de Piumhi (MG). In: CONGR. BRAS. GEOL., 31. Balneário de Camboriú 1980. Anais... Balneário de Camboriú, SBG, v. 5, p. 2906-2917.

FUCK, R. A.; JARDIM DE SÁ, E. F.; PIMENTEL, M. M.; DARDENNE, M. A.; PEDROSA SOARES, A. C. 1993. As faixas de dobramentos marginais do Cráton do São Francisco In: J. M. L. Dominguez, A, Misi (eds) O Cráton do São Francisco. Salvador, SBG/SGM/CNPq, pp. 161-185.
FUCK, R. A. 1994. A Faixa Brasília e a Compartimentação Tectônica na Província Tocantins. In: SIMP. GEOL. CENTRO-OESTE, 4. 1994. Atas.., SBG, p. 184-187.

HEILBRON, M.; VALERIANO, C. M.; ZIMBRES, E.; CHRISPIM, S.J.; SIMÕES, L. S. A.; SOUZA, M. A. T. 1987. O contato basal do Grupo Canastra entre Itaú de Minas e Carmo do Rio Claro. In: SIMP. GEOL. MINAS GERAIS, Belo Horizonte 1987. Atas... Belo Horizonte, SBG, p. $179-198$.

LADEIRA, E. A. 1985. Alguns temas polêmicos da geologia precambriana de Minas Gerais e sugestões de investigações para resolvê-los. In: SIMP. GEOL. MINAS GERAIS, 3. Belo Horizonte 1989. Anais... Belo Horizonte, SBG-MG, bol.5, p. 354-365.

MACHADO FILHO, L.; RIBEIRO, M.; GONZALES, S. R.; SCHENINI, C. A.; SANTOS NETO, A. DOS; PALMEIRA, R. C.; PIRES, J. L.; TEIXEIRA, W.; CASTRO, H. E. F. 1983. Geologia das folhas Rio de Janeiro (SF 23/24) escala 1:1.000.000, mapa e texto explicativo. Rio de Janeiro, RADAM Brasil-Ministério das Minas e Energia. 780p.

MACHADO, N. \& SCHRANK, A. 1989. Geocronologia U/Pb no maciço de Piumhi - resultados preliminares. In: SIMP. GEOL. MINAS GERAIS, 5. Belo Horizonte 1989. Anais... Belo Horizonte, SBG-MG, boi. 10, p. 45-49.

MAGALHÃES, P. M.; CHEMALE JR., F.; ALKMIN, F. F. 1989. Estilo tectônico da porção sul da Bacia do São Francisco. In: SIMP. GEOL. MINAS GERAIS, 5. Belo Horizonte 1989. Anais... Belo Horizonte, SBG-MG, boi. 10, p. 284-288.

MORALES, N.; CARVALHO, S. G.; CHOUDHURI, A.; FIORI, A. P.; M. A. F.; RODRIGUES, M. F. B.; SOARES, P. C.; ZANARDO, A. 1983. Geologia das folhas de Fortaleza de Minas, Alpinópolis, Jacuí e Nova Resende, MG. In: SIMP. GEOL. MINAS GERAIS, 2. Belo Horizonte 1993. Atas... Belo Horizonte, SBG-MG, boi. 3, p. 411-422.

NEVES, B. B. B. \& CORDANI, U. G. 1991. Tectonic evolution of South America during the Late Proterozoic. Precambrian Research, 53:23-40.

OLIVEIRA, M. A. F. DE; CARVALHO, S. G. DE; MORALES, N.; RODRIGUES, M. F. B.; ZANARDO, A. 1983. Geologia das quadrículas de Cássia e São Sebastião do Paraíso, MG. In: SIMP. GEOL. MINAS GERAIS, 2. Belo Horiznte 1983. Atas... Belo Horizonte, SBG-MG, boi. 3, p. 432-439. 
PASSCHIER, C. W. \&TROUW, R. A. J. (in press). Microtectonics. Springer, $289 \mathrm{p}$.

SCHOBBENHAUS, C.; CAMPOS, D.A; DERZE, G. R.; ASMUS, H. E. 1984. Mapa Geológico do Brasil e da Área Oceânica Adjacente. Escala 1:2.500.000. Brasília, MME/DNPM.

SCHRANK, A. 1982. Petrologie dês komatiites et dês roches associées de Ia ceintures verte du Massif Précambrien de Piumhi (Minas Gerais Brazil). Thèse 3ème Cycle, Université de Paris-sud, Orsay. $270 \mathrm{p}$.

SCHRANK, A \& SILVA, M. G. 1993. Os greenstone belts do Cráton do São Francisco, Brasil. In: J. M. L. Dominguez, A, Misi (eds) O Cráton do São Francisco. Salvador, SBG/SGM/CNPq, pp. 85-118.

SCHRANK, A. \& ABREU, F. R. 1990. Nova proposta de evolução estratigráfica e tectônica para o Maciço de Piumhi-SW de Minas Gerais. In: CONGR. BRAS. GEOL., 36, Natal 1990. Boletim de Resumos...Natal, SBG,p.331.

SCHRANK, A.; ABREU, F. R.; ROIG, H. L.; ROIG, bH. L.; CHOUDHURI, A.; SZABÓ, G. J. A.; CARVALHO, E. D. R. 1990. Determinação dos vetores de transporte tectônico na borda sudoeste 'do Cráton do São Francisco. In: CONGR. BRAS. GEOL., 36, Natal 1990. 4nais...Natal, SBG, v.5, p. 2276-2283.

SCHMIDT, W. \& FLEISCHER, R. 1978. Estilo estrutural do Precambriano no Sudeste de Minas Gerais. In: CONGR. BRAS. GEOL., 30. Recife 1978. Anais... Recife, SBG, v. 1, p. 431-434.

SIMÕES, L. S. A. 1995. Evolução tectonometamórfica da nappe de Passos, sudoeste de Minas Gerais. Tese de Doutorado, IG-Universidade de São Paulo. $149 \mathrm{p}$.

SIMÕES, L. S. A. \& VALERIANO, C. de M. 1990. Porção meridional da Faixa de Dobramentos Brasília: estágio atual do conhecimento e problemas de correlação tectono-estratigráfica. In: CONGR. BRAS. GEOL., 36. Natal 1990. Anais... Natal, SBG, v. 6, p. 2564-2575.

SIMÕES, L. S. A.; VALERIANO, C. DE M.; MORALES, N.; ZANARDO, A.; MORAES, R.; GOMI, C.Y. 1988. Zonação metamórfica inversa do Grupo Araxá-Canastra na região de São Sebastião do Paraíso-Alpinópolis, MG. In: CONGR. BRAS. GEOL., 35. Belém 1988. Anais... Belém, SBG, v. 3, p. 1203-1215.

SOUZA, J. C. A. A. 1943. Cromo em Piui, Estado de M.G. Avulso da Divisão de Fomento à Produção Mineral, DNPM, Rio de Janeiro, 50:1-27.

TASSINARI, C. C. G. \& CAMPOS NETO, M. C. 1988. Precambrian Continental Crust Evolution of the Southeastern São Paulo State Brazil- Based on Isotopic Evidences. Geochimica Brasiliensis 2(2): 175183.
TASSINARI, C. C. G.; KAWASHITA, K.; VAN SCHMUSS, R.; TAYLOR, P. N. 1988. As idades das rochas e dos eventos metamórficos da região sudeste do Estado de São Paulo. In: CONGR. BRAS. GEOL., 35, Belém 1988. Anais..., Belém, SBG, v. 6 pp. 2840-2853.

TEIXEIRA, N. A. \& DANNI, J. C. M. 1978. Contribuição à estratigrafia do Grupo Araxá na região de Passos, MG. In: CONGR. BRAS, GEOL., 30. Recife 1978. Anais... Recife, SBG, v. 2, p. 700-711.

TEIXEIRA, W. 1982. Geochronology of the Southern part of the São Francisco craton. Revista Brasileira de Geociências 12(1-3): 268-277.

TEIXEIRA, W. 1985. A evolução geotectônica da porção meridional do Cráton do São Francisco, com base em interpretações geocronológicas. Tese de Doutorado, IG-USP (inédito), $207 \mathrm{p}$.

TEIXEIRA, W.; AKIMOTO, H.; SIGA JR., O.; SATO, K. 1989. A evolução geocronológica dos terrenos granítico-gnáissico-migmatíticos ao sul da Faixa Canastra, sudoeste de Minas Gerais. In: SIMP. GEOL. MINAS GERAIS, 5. Belo Horizonte 1989. Anais... Belo Horizonte, SBG-MG, boi. 10, p. 243-246.

TEIXEIRA, W. \& FIGUEIREDO, M. C. H. 1991. An outline of Early Proterozoic crustal evolution in the São Francisco craton, Brazil: a review. Precambrian Research, 53: 1-22.

VALERIANO, C.M. 1992. Evolução tectônica da extremidade meridional da Faixa Brasilia, região da Represa de Furnas, Sudoeste de Minas Gerais. Tese de Doutorado, IG-Universidade de São Paulo. 192 p.

VALERIANO, C M.; SIMÕES, L. S. A.; GODOY, A. M. 1989. Compartimentação tectônica da porção meridional das Faixas Uruaçu e Brasília, SW de Minas Gerais: dados preliminares. In: SIMP. GEOL. MINAS GERAIS, 5. Belo Horizonte 1989. Atas... Belo Horizonte, SBG-MG, bol.10, p. 238-242.

VALERIANO, C. M.; SIMÕES, L. S. A. HEILBRON, M. 1993. Estruturação da porção meridional da Faixa Brasília, sudoeste de minas Gerais: implicações sobre a definição do limite regional do Cráton do São Francisco. In: SIMPÓSIO SOBRE O CRATON DO SÃO FRANCISCO. Evolução Tectônica e Metalogenética do Cráton do São Francisco, 2, Salvador 1993. Anais...Salvador, SBG/SGM/CNPq, pp. 275276.

MANUSCRITO No 862

Recebido em 31 de agosto de 1996

Revisão dos autores em 30 de novembro de 1996 Revisão aceita em 15 de janeiro de 1997 